\title{
Stereotactic radiotherapy is a useful treatment option for patients with medullary thyroid cancer
}

\author{
Aleksandra Kukulska ${ }^{1,2^{*}}$, Jolanta Krajewska ${ }^{1}$, Zofia Kołosza ${ }^{3}$, Aleksandra Grządziel ${ }^{4}$, Mateusz Gajek², \\ Ewa Paliczka-Cieślik', Dorota Syguła ${ }^{2}$, Kornelia Ficek ${ }^{2}$, Aneta Kluczewska-Gałka ${ }^{1}$ and Barbara Jarząb ${ }^{1}$
}

\begin{abstract}
The role of radiotherapy in advanced medullary thyroid carcinoma (MTC) is confined to patients in whom surgical treatment or the administration of tyrosine kinase inhibitors are not possible or contraindicated. High fractionated radiation doses during radiosurgery or fractionated stereotactic radiotherapy are applied to reduce cancer-related symptoms and stabilize irradiated lesions. This study aimed to retrospectively evaluate the therapeutic effect of stereotactic radiotherapy in MTC patients.

Material and methods: The study group involved 11 MTC patients, treated due to 16 cancer lesions, mainly bone metastases (10 lesions), lymph node (2 lesions) metastases, or liver metastases (2 lesions), one primary thyroid tumor, and one MTC recurrence in the thyroid bed. The fractionated and total radiation doses ranged between 5 and $12 \mathrm{~Gy}$ and 8-44 Gy, respectively. Six lesions were treated with a single radiation fraction, three lesions with 2 fractions, another 6 lesions with 3 fractions, whereas the remaining one metastatic lesion with 9 fractions of stereotactic radiosurgery.
\end{abstract}

Results: The beneficial effect of stereotactic radiosurgery was obtained in all treated lesions. None of treated lesions progressed in the further disease course. Fourteen lesions were stable (87.5\%), including eight lesions showing progression before radiosurgery (good response). Disease control was obtained in all soft-tissue metastases. Regarding bone metastases, partial regression was achieved in $20 \%$ lesions, whereas in $30 \%$ lesions progressive before radiotherapy, the treatment led to disease stabilization.

Conclusions: Our data pointed to the effectiveness of high-dose fractionated radiotherapy in MTC. However, an observation of a larger group of patients is required to confirm it.

Keywords: Medullary thyroid carcinoma, Radiosurgery, Stereotactic radiotherapy, Radiation treatment, Palliative radiotherapy

\footnotetext{
* Correspondence: aleksandra.kukulska@io.gliwice.pl

${ }^{1}$ Nuclear Medicine and Endocrine Oncology Department, Maria

Sklodowska-Curie National Research Institute of Oncology Gliwice Branch,

Wybrzeze AK 15, 44-101 Gliwice, Poland

${ }^{2}$ Radiotherapy Department, Maria Sklodowska-Curie National Research

Institute of Oncology Gliwice Branch, Wybrzeze AK 15, 44-101 Gliwice,

Poland

Full list of author information is available at the end of the article
}

(c) The Author(s). 2021 Open Access This article is licensed under a Creative Commons Attribution 4.0 International License, which permits use, sharing, adaptation, distribution and reproduction in any medium or format, as long as you give appropriate credit to the original author(s) and the source, provide a link to the Creative Commons licence, and indicate if changes were made. The images or other third party material in this article are included in the article's Creative Commons licence, unless indicated otherwise in a credit line to the material. If material is not included in the article's Creative Commons licence and your intended use is not permitted by statutory regulation or exceeds the permitted use, you will need to obtain permission directly from the copyright holder. To view a copy of this licence, visit http://creativecommons.org/licenses/by/4.0/. The Creative Commons Public Domain Dedication waiver (http://creativecommons.org/publicdomain/zero/1.0/) applies to the data made available in this article, unless otherwise stated in a credit line to the data. 


\section{Background}

Medullary thyroid carcinoma (MTC), a rare malignant neoplasm arising from $\mathrm{C}$ cells, represents less than $5 \%$ of all thyroid cancers. It may occur as a sporadic disease or part of a hereditary multiple endocrine neoplasia (MEN) syndromes [1-5]. Surgery based on total thyroidectomy and neck lymph node dissection is the main and most effective treatment option. Other standard oncological treatment modalities, including chemo and radiotherapy, demonstrate a limited efficacy in MTC [6].

The role of radiotherapy in MTC has been confined to patients in whom surgical treatment or the administration of tyrosine kinase inhibitors are not possible or contraindicated. Published data regarding the effectiveness of radiotherapy are equivocal [7-11]. It is routinely applied as palliative therapy. The current ATA (American Thyroid Association) guidelines recommend adjuvant radiotherapy in patients with a high risk of local recurrence [6]. Our previous paper showed that the effect of postoperative adjuvant radiotherapy with fractionated doses of 2 Gy did not significantly impact the risk of local relapse [12]. Higher fractionated radiation doses are usually applied in patients with metastatic disease to reduce cancer-related symptoms and stabilize irradiated lesions [13]. The administered fractionated dose is limited by the necessity to protect critical organs localized near irradiated lesions. We tend to use the highest radiation doses in the shortest time that are not related to the risk of radiation complications. Such an approach improves the patient's comfort as well as treatment effect.

Radiosurgery (single radiation dose) or fractionated stereotactic radiotherapy (few radiation doses), allowing for a precise concentration of a high radiation dose, fulfill the above-mentioned conditions [14]. Thanks to the appropriate selection of a large number of beams and frequent monitoring of the patient's position during a radiotherapy session, precise treatment is possible. Many beams from different directions are concentrated in the middle of the treated volume, providing a very high radiation dose, higher than the doses used in conventional treatment. In comparison, the use of frequent imaging of the patient with the $\mathrm{kV}$ radiation provides monitoring of selected anatomical structures and assessing their position with respect to the planned position. Maintaining the unchanged position of anatomical structures, including the target, relative to radiation beams, allows for delivering a high fractional dose and limitation of treatment to one or several sessions.

The systems consist of a linear accelerator mounted on a robotic arm, repositionable couch, x-ray cameras, and imaging panels. For moving targets, the synchrony camera is used.
From the classic C-arm accelerators, the CK system differs in the way the accelerator is moved. Many treatment beams can enter the patient's body from different directions by placing an accelerator on the robot. In the conventional accelerator, the gantry can rotate in one plane only. Moreover, in the CK system, patient imaging $(2 \mathrm{D} \mathrm{kV})$ is performed during the therapy session, between the beams. It is an automated process performed even several dozen times per fraction. Thus, the precision of treatment is ensured by frequent imaging of the patients and their repositioning. In moving tumors, the CK system provides synchronization of the accelerator movement with the patient's breathing. It is different from stereotactic treatment on classic accelerators, where mostly $3 \mathrm{D}$ before irradiation is performed.

Two main features of the CK system, i.e., the use of several hundred beams and frequent x-ray patient imaging during therapy, cause the session to last longer than on a conventional accelerator.

Our study aimed to evaluate the therapeutic effect of stereotactic radiotherapy in MTC patients.

\section{Methods}

The study group involved 11 MTC patients, treated due to 16 cancer lesions, subjected to a retrospective analysis. Eleven lesions were subjected to CK, whereas the remaining five lesions were irradiated on a conventional linear accelerator, including one patient with respiratory gating. The fractionated and total radiation doses ranged between 5 and 12 Gy and 8-44 Gy, respectively. Six lesions were treated with a single radiation fraction, three lesions with 2 fractions, another 6 lesions with 3 fractions, whereas the remaining one metastatic lesion with 9 fractions of stereotactic radiosurgery. We treated mainly bone metastases (10 lesions), lymph node metastases (2 lesions), liver metastases (2 lesions), one primary thyroid tumor, and one MTC recurrence in the thyroid bed (Table 1 - in a separate file). Apart from the symptoms related to the tumor itself, the indication for the treatment was disease progression confirmed by imaging studies.

Treatment response was evaluated by imaging studies. We evaluated the dynamics of bone lesions using $\mathrm{CT}$, whereas the dynamics of local recurrence, lymph node and liver metastases were evaluated according to RECIST criteria based on CT and MR, respectively. The result of the most recent imaging assessment following stereotactic radiotherapy, performed before another therapeutic procedure, was considered an outcome. Stabilization of a lesion progressing before radiotherapy or tumor size reduction was considered a good response.

Follow-up ranged between 1 and 9 years, mean was 3 years, median 1.5 years. 
Table 1 Characteristics of the study group

\begin{tabular}{|c|c|c|c|c|c|c|c|c|c|c|c|}
\hline Patient & sex & age & pT & $\mathrm{pN}$ & $M$ & target & $\begin{array}{l}\text { Treatment } \\
\text { method }\end{array}$ & $\begin{array}{l}\text { Treatment } \\
\text { date }\end{array}$ & $\begin{array}{l}\text { Fractionated } \\
\text { Dose [Gy] }\end{array}$ & $\begin{array}{l}\text { Total dose } \\
\text { [Gy] }\end{array}$ & $\begin{array}{l}\text { Follow- } \\
\text { up } \\
\text { [years] }\end{array}$ \\
\hline 1. & $\mathrm{~m}$ & 56 & 2 & 1 & $\begin{array}{l}\mathrm{LN} \text {, bones, } \\
\text { lungs }\end{array}$ & $\begin{array}{l}\text { Th1 } \\
\text { Th10 }\end{array}$ & $\begin{array}{l}\text { CK } \\
\text { CK }\end{array}$ & $\begin{array}{l}2012 \\
2018\end{array}$ & $\begin{array}{l}10 \\
6\end{array}$ & $\begin{array}{l}10 \\
18\end{array}$ & $\begin{array}{l}7 \\
1\end{array}$ \\
\hline 2. & $f$ & 44 & $x$ & 1 & bones & $\begin{array}{l}\text { Th7 } \\
\text { L4 }\end{array}$ & $\begin{array}{l}\text { CK } \\
\text { CK }\end{array}$ & $\begin{array}{l}2016 \\
2016\end{array}$ & $\begin{array}{l}10 \\
10\end{array}$ & $\begin{array}{l}30 \\
30\end{array}$ & $\begin{array}{l}3 \\
3\end{array}$ \\
\hline 3. & $f$ & 65 & $x$ & 1 & bones & Th8 & ST & & 10 & 10 & 8 \\
\hline 4. & $f$ & 75 & $x$ & 1 & $\begin{array}{l}\text { LN, bones } \\
\text { liver }\end{array}$ & Liver & ST-G & 2019 & 12 & 12 & 1 \\
\hline 5. & $f$ & 39 & 2 & 0 & bones, liver & $\begin{array}{l}\text { L4 } \\
\text { Th2 }\end{array}$ & $\begin{array}{l}\text { CK } \\
\text { CK }\end{array}$ & $\begin{array}{l}2012 \\
2011\end{array}$ & $\begin{array}{l}8 \\
8\end{array}$ & $\begin{array}{l}16 \\
16\end{array}$ & $\begin{array}{l}8 \\
9\end{array}$ \\
\hline 6. & $f$ & 60 & 3 & 1 & $\begin{array}{l}\text { bones, } \\
\text { liver }\end{array}$ & $\begin{array}{l}\text { Skull } \\
\text { Liver }\end{array}$ & $\begin{array}{l}\text { CK } \\
\text { CK }\end{array}$ & $\begin{array}{l}2012 \\
2012\end{array}$ & $\begin{array}{c}10 \\
8\end{array}$ & $\begin{array}{c}10 \\
8\end{array}$ & $\begin{array}{l}1 \\
1\end{array}$ \\
\hline 7. & $f$ & 65 & $x$ & 1 & $\begin{array}{l}\mathrm{LN}, \\
\text { liver }\end{array}$ & LN & CK & 2018 & 8 & 24 & 1 \\
\hline 8. & $\mathrm{~m}$ & 44 & 4 & 1 & bones & $\begin{array}{l}\text { Th6 } \\
\text { L1 }\end{array}$ & $\begin{array}{l}\text { CK } \\
\text { CK }\end{array}$ & $\begin{array}{l}2013 \\
2013\end{array}$ & $\begin{array}{r}7 \\
10\end{array}$ & $\begin{array}{l}21 \\
20\end{array}$ & $\begin{array}{l}1 \\
1\end{array}$ \\
\hline 9. & $f$ & 62 & 4 & 1 & $\begin{array}{l}\text { Lungs, local } \\
\text { recurrence }\end{array}$ & Recurrence & St & 2006 & 8 & 8 & 2 \\
\hline 10. & $\mathrm{~m}$ & 24 & 1 & 0 & 0 & $\begin{array}{l}\text { Primary thyroid } \\
\text { tumor }\end{array}$ & St & 2017 & 12 & 36 & 1 \\
\hline 11. & $\mathrm{~m}$ & 50 & 3 & 1 & $\begin{array}{l}\text { Retropharyngeal } \\
\text { LN }\end{array}$ & LN & CK & 2016 & 5 & 45 & 3 \\
\hline
\end{tabular}

LN lymph nodes, CK cyber knife, St Stereotactic radiotherapy

The study was approved, and the need of informed consent was exempted by the Bioethical Committee at M. Sklodowska-Curie National Research Institute of Oncology, Gliwice Branch $(\mathrm{KB} / 430-72 / 20)$ as the informed consent was not required by the bioethical committee.

Stereotactic plans were calculated in the BrainScan v. 5.31 (BrainLAB GmbH, Heimstetten, Germany) treatment planning system. Then successively, the latest versions of the software were used: iPlan v.3.0 since 2007 and iPlan v. 4.5 since 2011.

Treatment plans were implemented at Clinac 2300 Varian Medical Systems (Palo Alto, CA, USA) with the attached to the gantry. The $\mathrm{m} 3 \mu \mathrm{MLC}$ was developed jointly by BrainLAB GmbH and Varian Medical Systems. The $\mathrm{m} 3 \mathrm{had} 14$ pairs of $3 \mathrm{~mm}$ leave in the center of the field, 6 pairs of $4.5 \mathrm{~mm}$ leave in the middle, and six pairs of $5.5 \mathrm{~mm}$ leave at the periphery for a maximum field size of $9,8 \times 9,8 \mathrm{~cm}^{2}$. The dimension of the lives is defined in the isocenter.

Since the CK VSI system (Accuray, Sunnyvale, CA, USA) installation in 2010, stereotactic plans can also be delivered in a robotic manner. The CK system is equipped with two types of circular collimators: fixed and Iris variable aperture, both with diameters from $5 \mathrm{~mm}$ up to $60 \mathrm{~mm}$. Our Institute has also been using the modern CK M6 system, additionally equipped with a multi-leaf collimator, since 2018.
Dose distribution calculations are performed in two treatment planning systems: MultiPlan v. 4.6 and Precision v. 2.0 dedicated to VSI and M6 units, respectively.

Statistical analysis, carried out using Dell Inc. (2016) Dell Statistica version 13 and Stata/MP 13.1 for Windows, was based on the following tests: the exact Fisher's test and Mann-Whitney test.

\section{Results}

Stabilization after stereotactic radiosurgery was observed in the further disease course in all treated lesions. Fourteen lesions were stable (87.5\%), including eight lesions showing progression before radiosurgery (good response). While the volume of two other lesions significantly reduced. Good treatment response was obtained in $62.5 \%$ of lesions (10 out of 16 ). Treatment outcomes are summarized in Table 2.

Regarding bone metastases, partial regression was achieved in $2 / 10(20 \%)$ lesions, whereas in $3 / 10(30 \%)$ lesions, progressive before radiotherapy, the treatment led to disease stabilization.

Disease control was obtained in all soft-tissue metastases. $83 \%$ of them (5 lesions) demonstrated progression before radiosurgery.

Fractionated $(p=0.77)$ and cumulative $(p=0.586)$ radiation doses did not significantly differ between the group 
Table 2 Summary of radiotherapy outcomes

\begin{tabular}{|c|c|c|c|c|c|c|}
\hline Patient & Target & Treatment date & $\begin{array}{l}\text { Progression } \\
\text { prior to radiotherapy }\end{array}$ & Outcome & $\begin{array}{l}\text { Fractionated } \\
\text { dose }\end{array}$ & Total dose \\
\hline 1. & $\begin{array}{l}\text { Th1 } \\
\text { Th10 }\end{array}$ & $\begin{array}{l}2012 \\
2018\end{array}$ & $\begin{array}{l}\text { No } \\
\text { No data }\end{array}$ & $\begin{array}{l}\text { SD } \\
\text { No data }\end{array}$ & $\begin{array}{l}10 \text { Gy } \\
6\end{array}$ & $\begin{array}{l}10 \\
18\end{array}$ \\
\hline 2. & $\begin{array}{l}\text { Th7 } \\
\text { L4 }\end{array}$ & $\begin{array}{l}2016 \\
2016\end{array}$ & $\begin{array}{l}\text { No } \\
\text { No data }\end{array}$ & SD & $\begin{array}{l}10 \\
10\end{array}$ & $\begin{array}{l}30 \\
30\end{array}$ \\
\hline 3. & Th8 & 2008 & No & SD & 10 & 10 \\
\hline 4. & Liver & 2019 & YES & SD & 12 & 12 \\
\hline 5. & $\begin{array}{l}\text { L4 } \\
\text { Th2 }\end{array}$ & $\begin{array}{l}2012 \\
2011\end{array}$ & $\begin{array}{l}\text { No } \\
\text { No data }\end{array}$ & $\begin{array}{l}P R \\
P R\end{array}$ & $\begin{array}{l}8 \\
8\end{array}$ & $\begin{array}{l}16 \\
16\end{array}$ \\
\hline 6. & $\begin{array}{l}\text { Skull } \\
\text { Liver }\end{array}$ & $\begin{array}{l}2012 \\
2012\end{array}$ & $\begin{array}{l}\text { YES } \\
\text { YES }\end{array}$ & $\begin{array}{l}\text { SD } \\
\text { No data }\end{array}$ & $\begin{array}{l}10 \\
8\end{array}$ & $\begin{array}{c}10 \\
8\end{array}$ \\
\hline 7. & LN & 2018 & YES & SD & 8 & 24 \\
\hline 8. & $\begin{array}{l}\text { Th6 } \\
\text { L1 }\end{array}$ & $\begin{array}{l}2013 \\
2013\end{array}$ & $\begin{array}{l}\text { YES } \\
\text { YES }\end{array}$ & $\begin{array}{l}S D \\
S D\end{array}$ & $\begin{array}{l}7 \\
10\end{array}$ & $\begin{array}{l}21 \\
20\end{array}$ \\
\hline 9. & Recurrence & 2006 & No & SD & 8 & 8 \\
\hline 10. & Primary thyroid tumor & 2017 & YES & SD & 12 & 36 \\
\hline 11. & LN & 2016 & YES & SD & 5 & 45 \\
\hline
\end{tabular}

$S D$ stable disease, $P R$ partial response

with a good response (PR or SD in progressive lesions) and the remaining patients (Table 3 ).

There were no significant differences in outcomes regarding the localization of metastases $(p=0.44$; Table 4).

In one patient (patient $\mathrm{nr} 10$ ), stereotactic radiosurgery was the only therapeutic method of the primary, low advanced MTC tumor, which was not amendable for surgery due to important comorbidities. Stereotactic radiotherapy resulted in the stabilization of a previously progressive tumor and a decrease in serum calcitonin concentration.

There were no treatment-related radio-necrosis and any other severe complications observed during the further follow-up.

\section{Discussion}

Our results demonstrate a beneficial effect of highdose fractionated radiotherapy in MTC. However, a low number of analyzed patients did not allow us to draw definite conclusions. The rare MTC occurrence, especially in its advanced form, makes it impossible to collect a larger study group. However, one should notice, that our patients constitute one of the larger groups analyzed. The published data usually concerned with single MTC cases. Bernstein et al., who reported the outcomes of phase I/II trial concerning stereotactic radiotherapy in treating thyroid cancer vertebral metastases, involved only 4 MTC patients [15]. Boyce-Fappiano et al. analyzed a group of 67 thyroid cancer patients, 10 of which were medullary thyroid carcinoma cases. Stereotactic radiosurgery was used for metastatic spine tumors [16]. Other papers described single MTC patients with brain metastases [17-20]. Bernard et al. emphasized that the beneficial effect of radiosurgery was observed mainly in differentiated thyroid carcinoma [19]. The other authors reported good treatment outcomes considering the whole analyzed groups, with MTC patients comprising more than $20 \%$ of patients.

The highest percentage in our group constituted patients with bone metastases. Two metastatic bone lesions decreased their volume after radiotherapy, whereas the remaining eight bone lesions were stable, including three metastases with progression before

Table 3 Radiotherapy doses [Gy] with reference the treatment outcome

\begin{tabular}{|c|c|c|c|c|c|c|}
\hline & \multicolumn{3}{|c|}{ Fractionated dose [Gy] } & \multicolumn{3}{|c|}{ Total dose [Gy] } \\
\hline & $\begin{array}{l}\text { Mean } \pm \\
\text { SD }\end{array}$ & median & range & $\begin{array}{l}\text { Mean } \pm \\
\text { SD }\end{array}$ & median & range \\
\hline $\begin{array}{l}\text { Good treatment response (regression or stabilization of lesion progressed before } \\
\text { radiotherapy }\end{array}$ & $8.8 \pm 2.2$ & 8 & $5-12$ & $20.8 \pm 11.7$ & 18 & $8-45$ \\
\hline Remaining patients (disease stabilization) & $9 \pm 1.7$ & 10 & $6-10$ & $17.7 \pm$ & 14 & $8-30$ \\
\hline The whole group & $8.9 \pm 2.0$ & 9 & $5-12$ & $19.8+10.9$ & 17 & $8-45$ \\
\hline
\end{tabular}


Table 4 Localization of irradiated lesions

\begin{tabular}{llc}
\hline $\begin{array}{l}\text { Localization of } \\
\text { irradiated lesions }\end{array}$ & $\begin{array}{l}\text { Number of lesions showing } \\
\text { good treatment response }\end{array}$ & $\begin{array}{l}\text { The whole } \\
\text { group }\end{array}$ \\
\hline Bones & $5(50 \%)$ & 10 \\
Lymph nodes & $2(100 \%)$ & 2 \\
Liver & $2(100 \%)$ & 2 \\
$\begin{array}{l}\text { Recurrence in thyroid } \\
\text { bed }\end{array}$ & $0(0 \%)$ & 1 \\
$\begin{array}{l}\text { Primary thyroid } \\
\text { tumor }\end{array}$ & $1(100 \%)$ & 1 \\
\hline
\end{tabular}

radiosurgery. Similar data were reported by Bernstein et al. [15], who analyzed 23 patients, among them 4 MTC cases. Moreover, Boyce-Fappiano et al. analyzed a large group of patients and observed a good response for spine stereotactic radiotherapy in ten metastatic thyroid cancer cases [16]. The ability to stabilize spinal metastases is crucial because progression could lead to spinal cord injury, significantly worsening patients' quality of life. In addition to spinal metastases, tumors in the neck are the second group of lesions whose progression can cause significant damage to the patient's health. Timely radiotherapy can prevent dysphagia and shortness of breath caused by tumor expansion in the neck.

There were six soft-tissue metastases in our group, in which high-dose stereotactic radiotherapy resulted in beneficial outcomes. Similar effects were observed by Kim et al., who applied stereotactic radiosurgery in 9 patients with lymph node metastases in the course of thyroid carcinoma, among them 2 MTC cases [17]. The effectiveness of stereotactic radiotherapy in treating soft tissue metastases was confirmed by Ishigaki et al., who treated 25 patients diagnosed with differentiated thyroid cancer due to local recurrence not amendable for surgery [21]. Radiotherapy led to disease stabilization in all treated patients.

Although our group is not large enough to undergo a complete statistical evaluation and draw clear conclusions, it provides information for the clinician indicating the possibility of treatment of single MTC foci that cannot be removed surgically. Nevertheless, one should stress, our study group consisted only of MTC patients. It allowed us to conclude on the usefulness of stereotactic radiotherapy in treating these patients with somewhat more certainty than in the case of mixed groups as MTC biology and treatment methods differ from other types of thyroid cancer. So, a pooled analysis of all thyroid cancer patients may result in imprecise conclusions. It would be valuable to be able to confirm our results on a larger group of patients.

We believe our study will be helpful in clinical decision-making regarding the management of patients with metastatic or locally advanced medullary thyroid cancer, supporting the clinician in the treatment of patients for whom radiotherapy may be the only feasible treatment modality. The short time, satisfactory efficacy, and the lack of severe treatment-related complications of stereotactic radiotherapy allow applying it in patients in a more severe general condition, not amendable for surgery or systemic treatment.

\section{Conclusions}

To conclude, our data pointed to the effectiveness of high-dose fractionated radiotherapy in MTC. However, an observation of a larger group of patients is required to confirm it.

\section{Abbreviations \\ ATA: American Thyroid Association; CBCT: Cone-beam computed tomography; CK: Cyber-knife ; CT: Computed tomography ; MEN: Multiple endocrine neoplasia; MRI: Magnetic resonance; MTC: Medullary thyroid carcinoma; PR: Partial regression ; SD: Disease stabilization; $\mu$ MLC: Micro multi-leaf collimator}

\section{Acknowledgements}

Not applicable.

\section{Authors' contributions}

Aleksandra Kukulska was responsible for conception and drafted the manuscript. Jolanta Krajewska drafted the work. Zofia Kolosza was responsible for the analysis and interpretation of the data. Aleksandra Grządziel, Mateusz Gajek, Ewa Paliczka-Cieslik, Dorota Sygula, Kornelia Ficek and Aneta Kluczewska-Galka were responsible for acquisition of the data. Barbara Jarząb supervised work. All of the authors approved the submitted version of the manuscript and agreed to be personally accountable for the author's own contributions and to ensure that questions related to the accuracy or integrity of any part of the work.

\section{Funding}

This research did not receive any specific grant from any funding agency in the public, commercial, or not-for-profit sector.

\section{Availability of data and materials}

The datasets used and analyzed during the current study are available from the corresponding author on reasonable request.

\section{Declarations}

Ethics approval and consent to participate

The study was approved by the Ethics Committee at M. Sklodowska-Curie National Research Institute of Oncology, Gliwice Branch (KB/430 - 72/20). Ethics Committee exempts this research from consent to participate. The study was carried out in accordance with the Declaration of Helsinki.

Consent for publication

Not applicable.

\section{Competing interests}

The authors declare that there is no conflict of interest that could be perceived as prejudicing the impartiality of the research reported.

\section{Author details}

${ }^{1}$ Nuclear Medicine and Endocrine Oncology Department, Maria Sklodowska-Curie National Research Institute of Oncology Gliwice Branch, Wybrzeze AK 15, 44-101 Gliwice, Poland. Radiotherapy Department, Maria Sklodowska-Curie National Research Institute of Oncology Gliwice Branch, Wybrzeze AK 15, 44-101 Gliwice, Poland. ${ }^{3}$ Department of Biostatistics and Bioinformatics, Maria Sklodowska-Curie National Research Institute of Oncology Gliwice Branch, Gliwice, Poland. ${ }^{4}$ Radiotherapy Planning 
Department, Maria Sklodowska-Curie National Research Institute of Oncology Gliwice Branch, Gliwice, Poland.

Received: 14 March 2021 Accepted: 25 July 2021

Published online: 09 August 2021

\section{References}

1. Pacini F, Castagna MG, Cipri C, Schlumberger M. Medullary thyroid carcinoma. Clin Oncol (R Coll Radiol). 2010;22:475-85. https://doi.org/10.101 6/j.clon.2010.05.002.

2. Maxwell JE, Sherman SK, O'Dorisio TM, Howe JR. Medical management of metastatic medullary thyroid cancer. Cancer. 2014;120:3287-301. https://doi. org/10.1002/cncr.28858.

3. Leboulleux S, Baudin E, Travagli J-P, Schlumberger M. Medullary thyroid carcinoma. Clin Endocrinol (Oxf). 2004;61:299-310. https://doi.org/10.1111/ j.1365-2265.2004.02037.x.

4. Kloos RT, Eng C, Evans DB, Francis GL, Gagel RF, Gharib H, Moley JF, Pacini $F$, Ringel MD, Schlumberger M, et al. Medullary thyroid cancer: management guidelines of the American Thyroid Association. Thyroid. 2009; 19:565-612. https://doi.org/10.1089/thy.2008.0403.

5. Moers AM, Landsvater RM, Schaap C, van Jansen-SchillhornVeen JM, de Valk IA, Blijham GH, Höppener JW, Vroom TM, van Amstel HK, Lips CJ. Familial medullary thyroid carcinoma: not a distinct entity? Genotype-phenotype correlation in a large family. Am J Med. 1996;101:635-41. https://doi.org/1 0.1016/s0002-9343(96)00330-0.

6. Wells SA, Asa SL, Dralle H, Elisei R, Evans DB, Gagel RF, Lee N, Machens A, Moley JF, Pacini F, et al. Revised American Thyroid Association guidelines for the management of medullary thyroid carcinoma. Thyroid. 2015;25:567610. https://doi.org/10.1089/thy.2014.0335.

7. Tubiana M, Haddad E, Schlumberger M, Hill C, Rougier P, Sarrazin D. External radiotherapy in thyroid cancers. Cancer. 1985;55:2062-71. https:// doi.org/10.1002/1097-0142(19850501)55:9+<2062::aid-cncr2820551406>3.0. co;2-o.

8. Samaan NA, Schultz PN, Hickey RC. Medullary Thyroid Carcinoma: Prognosis of Familial Versus Sporadic Disease and the Role of Radiotherapy. J Clin Endocrinol Metab. 1988;67:801-5. https://doi.org/10.1210/jcem-67-4-801.

9. Brierley J, Tsang R, Simpson WJ, Gospodarowicz M, Sutcliffe S, Panzarella T. Medullary Thyroid Cancer: Analyses of Survival and Prognostic Factors and the Role of Radiation Therapy in Local Control. Thyroid. 1996;6:305-10. https://doi.org/10.1089/thy.1996.6.305.

10. Schwartz DL, Rana V, Shaw S, Yazbeck C, Ang KK, Morrison WH, Rosenthal DI, Hoff A, Evans DB, Clayman GL, et al. Postoperative radiotherapy for advanced medullary thyroid cancer-local disease control in the modern era. Head Neck. 2008;30:883-8. https://doi.org/10.1002/hed.20791.

11. Compagnon F, Zerdoud S, Rives M, Laprie A, Sarini J, Grunenwald S, Chaltiel L, Graff P. [Postoperative external beam radiotherapy for medullary thyroid carcinoma with high risk of locoregional relapse]. Cancer Radiother. 2016;20: 362-9. https://doi.org/10.1016/j.canrad.2016.05.010.

12. Kukulska A, Krajewska J, Kolosza Z, Paliczka-Cieslik E, Kropinska A, Pawlaczek A, Puch Z, Ficek K, Lisik T, Sygula D, Wygoda Z. The role of postoperative adjuvant radiotherapy in the local control in medullary thyroid carcinoma. Endocr Connect 2019;9. https://doi.org/10.1530/EC-19-0387.

13. Jayarangaiah A, Sidhu G, Brown J, Barrett-Campbell O, Bahtiyar G, Youssef I, Arora S, Skwiersky S, McFarlane SI. Therapeutic options for advanced thyroid cancer. Int J Clin Endocrinol Metab. 2019;5:26-34. https://doi.org/10.17352/ ijcem.000040.

14. Ding C, Saw CB, Timmerman RD. Cyberknife stereotactic radiosurgery and radiation therapy treatment planning system. Med Dosim. 2018;43:129-40. https://doi.org/10.1016/j.meddos.2018.02.006.

15. Bernstein MB, Chang EL, Amini B, Pan H, Cabanillas M, Wang XA, Allen PK, Rhines LD, Tatsui C, Li J, et al. Spine Stereotactic Radiosurgery for Patients with Metastatic Thyroid Cancer: Secondary Analysis of Phase I/II Trials. Thyroid. 2016;26:1269-75. https://doi.org/10.1089/thy.2016.0046.

16. Boyce-Fappiano D, Gjyshi O, Pezzi TA, Allen PK, Solimman M, Taku N, Bernstein MB, CabanillasME, Amini B, Tatsui CE, Rhines LD, Wang XA, Briere TM, Yeboa DN, Bishop AJ, Li J, Ghia AJ. Spine stereotactic radiosurgery for metastatic thyroid cancer: a single-institution experience. JNeurosurg Spine. 2020;32:941-9.

17. Kim JH, Kim M-S, Yoo SY, Lim SM, Lee GH, Yi KH. Stereotactic body radiotherapy for refractory cervical lymph node recurrence of nonanaplastic thyroid cancer. Otolaryngol Head Neck Surg. 2010;142:338-43. https://doi. org/10.1016/j.otohns.2009.12.034.

18. Kim I-Y, Kondziolka D, Niranjan A, Flickinger JC, Lunsford LD. Gamma knife radiosurgery for metastatic brain tumors from thyroid cancer. J Neurooncol. 2009;93:355-9. https://doi.org/10.1007/s1 1060-008-9783-2.

19. Bernad DM, Sperduto PW, Souhami L, Jensen AW, Roberge D. Stereotactic radiosurgery in the management of brain metastases from primary thyroid cancers. J Neurooncol. 2010;98:249-52. https://doi.org/10.1007/s11060-0100175-z.

20. Simões-Pereira J, Macedo D, Bugalho MJ. Clinical outcomes of a cohort of patients with central nervous system metastases from thyroid cancer. Endocr Connect. 2016;5:82-8. https://doi.org/10.1530/EC-16-0049.

21. Ishigaki T, Uruno T, Tanaka T, Ogimi Y, Masaki C, Akaishi J, Hames KY, Yabuta T, Suzuki A, Tomoda C, et al. Usefulness of Stereotactic Radiotherapy Using the CyberKnife for Patients with Inoperable Locoregional Recurrences of Differentiated Thyroid Cancer. World J Surg. 2019;43:513-8. https://doi.org/1 0.1007/s00268-018-4813-5.

\section{Publisher's Note}

Springer Nature remains neutral with regard to jurisdictional claims in published maps and institutional affiliations.

\section{Ready to submit your research? Choose BMC and benefit from:}

- fast, convenient online submission

- thorough peer review by experienced researchers in your field

- rapid publication on acceptance

- support for research data, including large and complex data types

- gold Open Access which fosters wider collaboration and increased citations

- maximum visibility for your research: over $100 \mathrm{M}$ website views per year

At $\mathrm{BMC}$, research is always in progress.

Learn more biomedcentral.com/submissions 